\title{
Penggunaan Matrix Analytic Technique pada Perhitungan Parameter Kinerja Proses Handoff
}

\author{
R. Hadianti, J. Naiborhu \& L. Dahliantini
}

Departemen Matematika, FMIPA, Institut Teknologi Bandung.

Jl. Ganesa 10, Bandung 40132, INDONESIA, Fax :062-22-2506450

e-mail: hadianti@dns.math.itb.ac.id, janson@dns.math.itb.ac.id, liadahliantini@yahoo.com

\begin{abstract}
Abstrak. Makalah ini membahas nilai-nilai parameter kinerja proses handoff pada sistem telekomunikasi bergerak seluler dengan pengaturan kanal dikerjakan dengan cara Fixed Channel Assignment dan muatan traffic yang homogen. Parameter kinerja yang dibahas adalah blocking probability dan dropping probability dari sinyal permintaan handoff, juga blocking probability dari sinyal permintaan hubungan baru.

Operator sistem telekomunikasi bergerak seluler biasanya memberikan prioritas pelayanan kepada sinyal permintaan handoff. Di makalah ini, prioritas tersebut diberikan melalui reservasi sejumlah kanal yang hanya dapat digunakan oleh sinyal permintaan handoff. Sejumlah kanal sisa diperuntukkan bagi sinyal permintaan hubungan baru, dan untuk waktu-waktu tertentu dapat juga digunakan oleh sinyal permintaan handoff. Dengan pemberian prioritas seperti ini, proses kedatangan sinyal-sinyal dan proses pelayanannya dapat dimodelkan menjadi suatu jaringan antrian yang terdiri dari dua sistem antrian: satu sistem antrian khusus untuk sinyal permintaan handoff dan satu sistem antrian dengan dua jenis masukan.

Kinerja jaringan antrian yang menjadi model masalah dianalisis dengan menurunkan suatu proses Markov dengan dua keadaan. Sistem persamaan kesetimbangan dari proses Markov, yang merupakan sistem untuk mendapatkan distribusi peluang stasioner dari proses Markov, diselesaikan dengan menerapkan Matrix Analytic Technique secara paralel pada dua sub matriks dari matriks generator proses Markov, kemudian kita menggunakan persamaan normalisasi untuk menggabungkan kedua hasil paralel tersebut.
\end{abstract}

Kata Kunci: proses handoff; proses Markov; matriks; generator; Matrix Analytic Technique.
Abstract. This paper discusses performance evaluation of mobile cellular telecommunication system that is related to the handoff process. We focus our discussion to the system with fixed channel assignment and homogeneous traffic. Performance parameters we discuss in this paper are the blocking probability and the dropping probability of handoff signals, and the blocking probability of new originating call signals.
The operator of the system usually gives a service priority to handoff signals compare to new originating call signals. In this paper, the priority is given

Makalah diterima redaksi tanggal 5 Oktober 2004, revisi diterima tanggal 26 April 2005, diterbitkan tanggal 19 Juni 2005. 
through channels reservation. A number of channels are reserved so that they can be used only for serving handoff signals. The remaining channels are used for serving new originating call signals and if there is an idle channel, it also can be used for serving handoff signals. With this priority, the arrival process and the service process of both types of signals can be modelled as a queueing network that consists of two queueing systems: one system for handoff signals and one system for both signals.

The performance of the queueing network is analyzed by deriving the a twodimensional Markov process. The system of balance equations of the process, which is needed for obtaining the stationary probability distribution of the process, is a large system. We solve this system by applying Matrix Analytic Technique to the two sub-systems simultaneously. The performance parameter values, which are expressed by the stationary probability distribution, are obtained from the solution.

Keywords: handoff process; Markov process; generator matrix; Matrix Analytic Technique.

2000 Mathematics Subject Classification: Primary: 90B22. Secondary: 60K30, $68 \mathrm{M} 20$.

\section{$1 \quad$ Pendahuluan}

Layanan sistem komunikasi bergerak seluler di Indonesia telah tersebar secara luas dalam dekade terakhir, dan mengalami peningkatan jumlah pengguna yang sangat pesat. Padahal lebar frekuensi yang dialokasikan untuk sistem ini tetap, dan tidak bisa diperluas. Karena itu, agar kinerja sistem tetap memenuhi standar yang telah ditetapkan, diperlukan optimisasi pada setiap proses yang terjadi di sistem ini.

Perangkat keras sistem telekomunikasi bergerak seluler pada umumnya terbagi atas 3 sub sistem utama (penjelasan selengkapnya lihat di buku Lee[5]) yaitu: MS (Mobile Station) atau dikenal dengan pesawat telefon yang biasa digunakan pengguna, Base Station Sub System dan Network Sub System dengan perangkatperangkat di tiap sub sistem ini seperti yang terlihat di gambar 1. Dari beberapa perangkat keras yang ada di sistem telekomunikasi ini, kita tertarik melihat kerja sistem yang terjadi antara MS (Mobile Station) dan BTS (Base Transceiver Station). BTS merupakan suatu perangkat yang menghubungkan sinyal dari suatu MS ke perangkat lainnya.

Operator sistem akan mengalokasikan suatu himpunan selang frekuensi yang akan dipakai untuk melayani hubungan telekomunikasi di daerah sekitar BTS itu ditempatkan. Selang frekuensi ini dikenal dengan nama kanal. Daerah cakupan satu BTS ini dinamakan suatu sel, dan setiap sel yang saling 
bertetangga akan memiliki himpunan kanal yang berbeda untuk menghindari adanya interferensi. Satu kanal dapat melayani satu hubungan telekomunikasi, sehingga satu sel pada saat yang bersamaan dapat melayani beberapa hubungan, banyaknya bergantung kepada banyaknya kanal yang dialokasikan pada sel tersebut. Kita fokuskan penelitian kita pada sistem dengan pengaturan kanal mengikuti aturan Fixed Channel Assignment, artinya banyaknya kanal yang dialokasi pada suatu sel nilainya tetap.

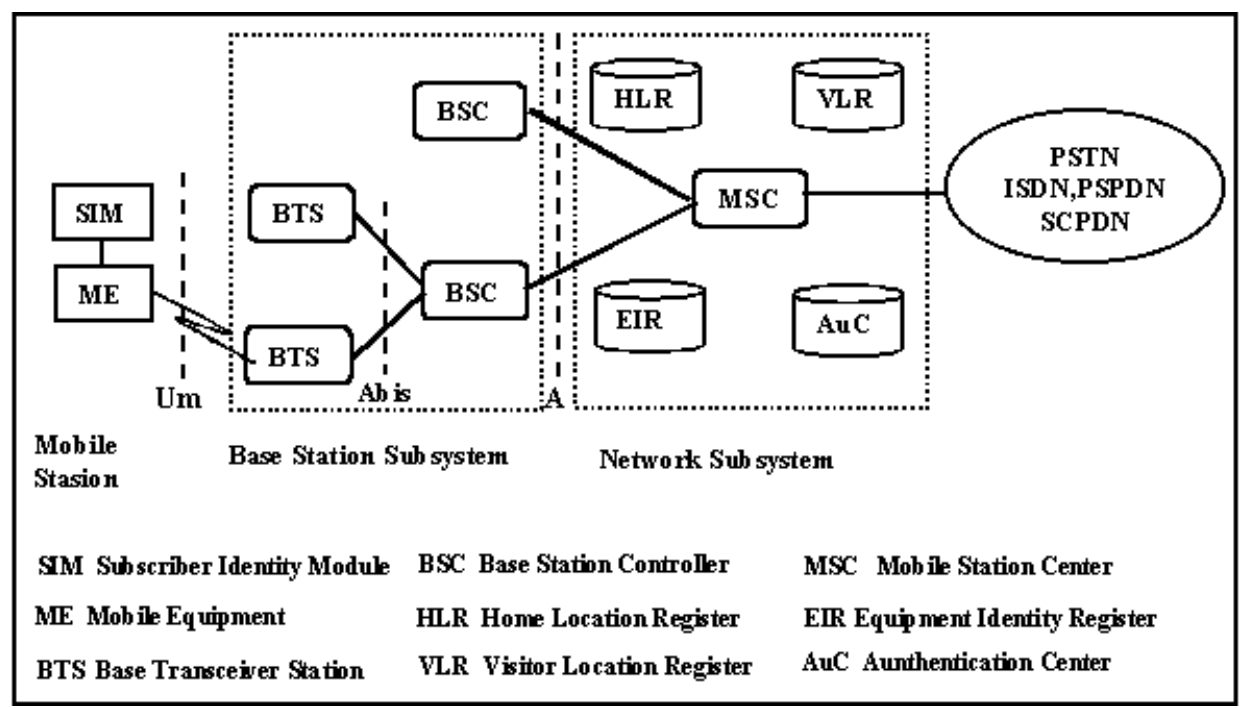

Gambar 1 Arsitektur umum sistem komunikasi bergerak seluler.

Pada sistem ini, seorang pengguna mempunyai keleluasaan untuk melakukan hubungan komunikasi sambil bergerak. Pergerakan pengguna pada suatu saat akan menjauhi sel asal dan menuju sel baru. Keadaan ini menyebabkan daya sinyal dari BTS asal akan menurun dan daya sinyal dari BTS tujuan akan menguat. Apabila kualitas daya sinyal pada BTS asal telah mencapai ambang batas daya terima, maka hubungan dengan BTS asal akan dilepas dan secara otomatis hubungan akan ditangani oleh BTS tujuan. Peristiwa pemindahan frekuensi secara otomatis dari sel asal ke sel tujuan ini dinamakan handoff.

Mengingat seorang pengguna akan lebih merasa tidak nyaman jika hubungan komunikasi yang sedang dia lakukan terputus daripada tidak memperoleh kanal saat melakukan hubungan baru, maka proses handoff lebih diprioritaskan dibandingkan permintaan hubungan baru. Salah satu teknis pemberian prioritas untuk proses handoff ini adalah dengan cara mereservasi sejumlah kanal yang tersedia pada suatu sel hanya untuk melayani proses handoff. Pemberian reservasi kanal ini dijelaskan pada paragraf berikut. 


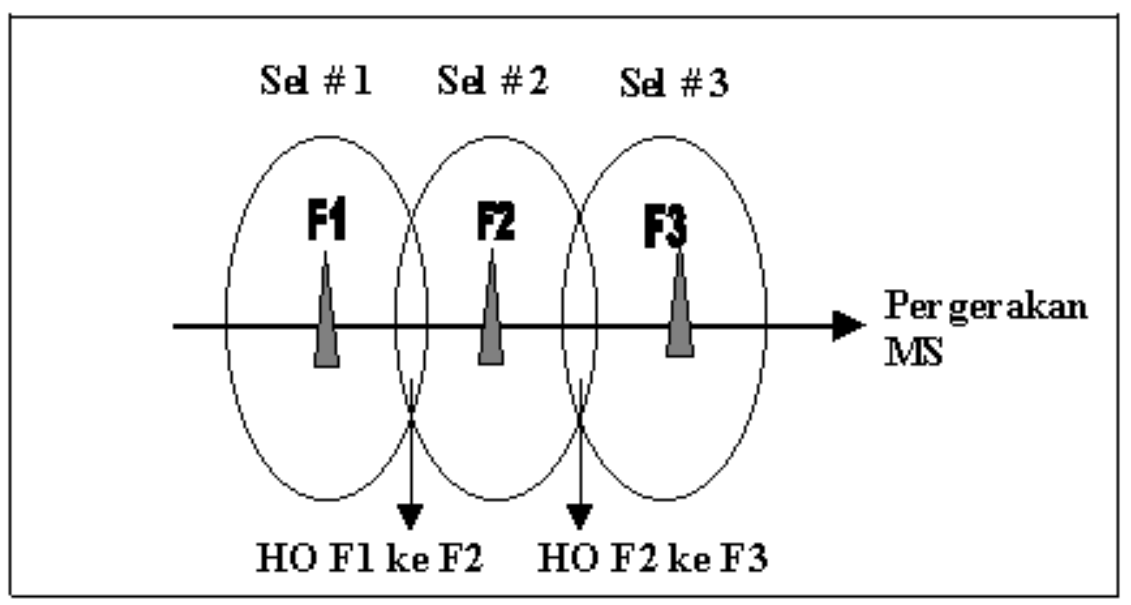

Gambar 2 Proses terjadinya handoff.

Pandang sel 1 dan sel 2 di gambar 2. Misalkan pada sel $i$ kita dialokasikan himpunan kanal $F_{i}, i=1,2$. Notasikan banyaknya kanal di himpunan $F_{i}$ sebagai $C_{i}$. Sekarang kita pandang proses handoff yang terjadi akibat pergerakan dari pengguna dari sel $1 \mathrm{ke}$ sel 2. Pada suatu saat, BTS di sel 2 akan menerima sinyal dari pengguna tersebut dan BTS 2 mengkategorikan sinyal tersebut sebagai sinyal handoff. Pada saat yang sama, BTS 2 mungkin sedang melakukan proses call set up untuk beberapa pengguna yang telah berada di sel 2. Untuk memberi prioritas pada sinyal handoff yang harus dilakukan BTS 2, maka sebagian dari $C_{2}$ kanal yang dialokasikan untuk BTS 2 ini diperuntukkan hanya untuk menangani proses handoff sementara sisanya dapat digunakan untuk melayani call set up pengguna yang berada di sel 2 .

Dengan cara mereservasi sejumlah kanal seperti yang telah dijelaskan sebelumnya, diharapkan peluang terputusnya hubungan komunikasi karena gagalnya proses handoff, yang kemudian kita namakan dropping probability dari proses handoff, dapat diturunkan nilainya. Tetapi teknik reservasi kanal ini akan mengakibatkan naiknya nilai blocking probability, yaitu peluang tertolaknya permintaan hubungan baru, karena jumlah kanal untuk melayani hubungan baru yang tersedia menjadi lebih sedikit. Di makalah ini kita akan menurunkan model antrian untuk pemberian prioritas proses handoff dengan reservasi kanal, dan menganalisa sistem antrian yang terbentuk untuk menentukan nilai-nilai dropping probability dan blocking probability dari sistem. Dari hasil ini kita akan dapat mengetahui jumlah kanal yang harus direservasi agar nilai-nilai dropping probability dan blocking probability masih memenuhi standar Grade of Service, yaitu dibawah 5\%. 
Teknik reservasi adalah salah satu teknik pemberian prioritas yang telah lama dikenal di Teori Antrian. Khusus untuk pemberian prioritas sinyal handoff, teknik ini telah dipelajari oleh K. Ioannou et al.[4] dan S. Radityo[8]. Di penelitian [8] diasumsikan terdapat dua kelas kecepatan pengguna, dan nilainilai parameter kinerja proses diperoleh dengan teknil simulasi. Sementara itu, di penelitian [4] diasumsikan terdapat satu kelas kecepatan gerak pengguna, dan nilai blocking probability baik untuk sinyal permintaan handoff ataupun untuk sinyal permintaan hubungan baru diperoleh dari hasil analisis sistem antrian $M / M / C / C+k$. Hasil yang diperoleh di penelitian ini serupa dengan yang diperoleh di tugas akhir Anditto Heristyo[3]. Di makalah ini, kita juga mengasumsikan terdapat satu kelas kecepatan gerak pengguna, dan nilai-nilai parameter kinerja sistem akan diturunkan dengan cara menurunkan satu jaringan antrian dan menganalisa kinerja jaringan antrian tersebut. Penurunan jaringan antrian dan analisis yang dimaksud telah dilakukan di penelitian R. Hadianti et al.[2], dengan hasil utama yang berupa algoritma untuk mendapatkan batas reservasi yang optimal. Dengan analasis yang dilakukan di [2], kita tidak hanya dapat menentukan blocking probability dari sinyal permintaan handoff dan sinyal permintaan hubungan baru, tetapi juga dapat menentukan dropping probability dari sinyal permintaan handoff. Nilai optimal dari jumlah kanal yang harus direservasi diperoleh dengan mempertimbangkan ketiga nilai peluang tersebut.

Salah satu proses untuk menentukan nilai optimal dari jumlah kanal yang harus direservasi adalah menentukan distribusi peluang stasioner dari proses Markov yang termuat di jaringan antrian. Untuk jumlah kanal yang cukup banyak, penentuan distribusi peluang stasioner ini memerlukan satu teknik khusus karena dengan teknik konvensional, seperti operasi baris elementer pada matriks, tidak akan efektif jika kita gunakan di sini. Makalah ini membahas teknik untuk mempercepat proses mendapatkan distribusi peluang stasioner tersebut, yang dikenal dengan nama Matrix Analytic Technique.

Makalah ini ditulis dengan susunan berikut. Sesudah latar belakang masalah, di bagian 2 kita akan menurunkan suatu sistem antrian yang merupakan model dari peristiwa pelayanan sinyal handoff dan sinyal originating call. Dari sistem antrian ini kita akan meneliti kinerja sistem, terutama untuk nilai dropping probability dan blocking probability. Penelitian kinerja ini dilakukan di bagian 3. Di bagian 4 didiskusikan Matrix Analytic Technique yang dapat kita gunakan untuk mendapatkan distribusi peluang stasioner dari proses Markov yang kita turunkan dari jaringan antrian. Di sub-bagian 4.4 kita akan melihat penggunaan Matrix Analytic Technique secara jelas pada suatu contoh kasus dari sistem telekomunikasi bergerak seluler yang sederhana. Sebagai penutup, di bagian 5 akan didiskusikan masalah-masalah yang belum terselesaikan dan arah penelitian lanjutan. 


\section{Model Antrian}

Di bagian ini kita akan menurunkan suatu sistem antrian yang merupakan model dari peristiwa pelayanan sinyal handoff dan sinyal originating call. Sebelumnya, kita perhatikan beberapa asumsi berikut.

Pada sistem ini, pengalokasian kanal dikerjakan dengan metoda metoda Fixed Channel Assignment (FCA). Artinya pada suatu BTS dialokasikan sejumlah kanal dengan jumlah tertentu. Traffic load pada sistem diasumsikan homogen, artinya rata-rata laju kedatangan sinyal (handoff dan originating call) tidak berubah terhadap waktu. Dengan kedua asumsi ini, maka kinerja sistem dapat dianalisa dengan menganalisa kinerja dari suatu sel. Kinerja dari sistem didapat dengan cara mencari rata-rata dari parameter kinerja sel.

Sekarang pandang suatu BTS di sistem. Misalkan pada BTS tersebut dialokasikan sebanyak $C$ kanal. Dengan teknik reservasi kanal, misalkan

(i) sejumlah $C_{l}$ kanal hanya diperuntukkan untuk melayani permintaan handoff,

(ii) sejumlah $C_{2}=C-C_{1}$ kanal sisanya diperuntukkan untuk melayani permintaan hubungan baru. Tetapi jika pada suatu saat permintaan handoff datang dan seluruh $C_{1}$ kanal sedang dipakai sementara paling sedikit satu dari $C_{2}$ kanal kosong, maka permintaan handoff tersebut dapat menggunakan kanal kosong tersebut. Artinya, $C_{2}$ kanal ini diperuntukkan untuk melayani sinyal (handoff dan sinyal originating call).

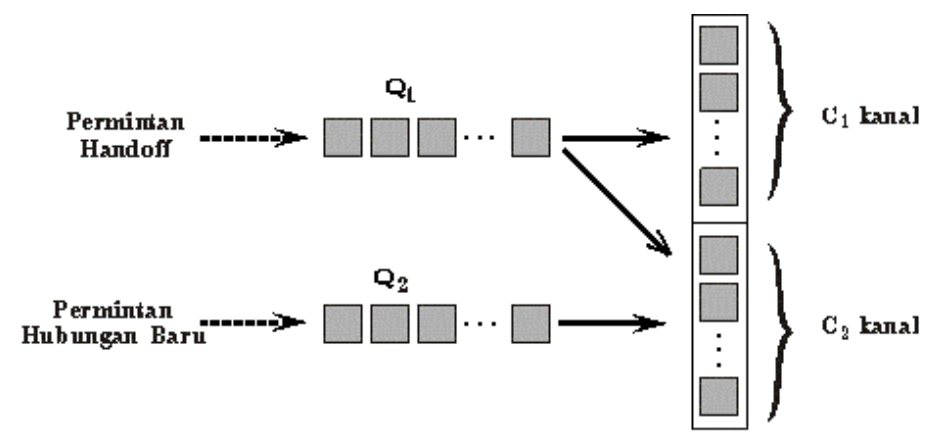

Gambar 3 Model sistem antrian pada suatu BTS.

Pada umumnya, operator sistem telekomunikasi ini akan membuat sinyal yang datang dan menemui semua kanal sibuk mengantri untuk beberapa saat dengan harapan beberapa saat kemudian ada kanal yang berubah menjadi kosong. Proses kedatangan, menunggu di antrian (jika harus menunggu), dan proses 
pelayanan oleh kanal-kanal yang tersedia, dapat dipandang sebagai suatu sistem antrian, dengan karakteristik sebagaimana digambarkan di gambar 3. Di sistem antrian ini kita mempunyai dua jenis masukan, yaitu masukan berupa sinyalsinyal handoff dan masukan yang berupa sinyal-sinyal originating call. Kita mengasumsikan bahwa proses kedatangan sinyal handoff dan proses kedatangan sinyal originating call merupakan dua proses Poisson yang saling bebas dengan masing-masing lajunya $\lambda_{h}$ dan $\lambda_{o}$. Selain itu, kita juga mengasumsikan bahwa pelayanan (proses transmisi+ waktu pembicaraan) untuk kedua jenis sinyal ini berdistribusi eksponensial dengan parameter $\mu$. Dengan asumsi-asumsi ini kita akan mempunyai suatu jaringan antrian yang, menurut notasi di buku Akimaru dan Kawashima[1], dikenal dengan sistem $M_{1} \overrightarrow{+} M_{2} / M / C\left(Q_{1}, Q_{2}\right)$. Sistem antrian ini terdiri dari dua buah antrian, yaitu sistem antrian $M / M / C_{1} / C_{1}+Q_{1}$ dan sistem antrian $M / M / C_{2} / C_{2}+Q_{2}$ dengan laju kedatangan pada sistem kedua bergantung kepada keadaan sistem pertama dan sistem kedua sendiri, dan $Q_{i}$ menyatakan kapasitas tempat mengantri di sistem $M / M / C_{i} / C_{i}+Q_{i}$, dan $C_{1}+C_{2}=C$. Selanjutnya kita namakan sistem $M / M / C_{1} / C_{1}+Q_{1}$ sebagai sistem antrian 1 dan sistem $M / M / C_{2} / C_{2}+Q_{2}$ sebagai sistem antrian 2 .

Untuk menganalisa kinerja dari jaringan antrian di atas, kita definisikan proses

$$
\left\{\left(X_{1}(t), X_{2}(t)\right), t \geq 0\right\},
$$

dengan $X_{1}(t)$ menyatakan banyaknya sinyal yang ada di sistem antrian $i$ pada saat $t, i=1,2$. Dengan asumsi-asumsi tentang proses kedatangan sinyal handoff dan sinyal originating call dan proses pelayanan seperti yang dijelaskan di bagian sebelumnya, proses $\left\{\left(X_{1}(t), X_{2}(t)\right), t \geq 0\right\}$ akan merupakan suatu proses Markov kontinu dengan ruang keadaan

$$
S=\left\{(i, j) \mid 0 \leq i \leq K_{1}, 0 \leq j \leq K_{2}\right\} \backslash\left\{(i, j) \mid i>C_{1} \text { dan } j<C_{2}\right\}
$$

dengan $K_{i}=C_{i}+Q_{i}, i=1,2$. Kita asumsikan $\rho=\left(\lambda_{h}+\lambda_{o}\right) / C \mu<1$ sehingga

$$
\left.\pi_{i, j}=\lim _{t \rightarrow \infty} P\left(X_{1}(t), X_{2}(t)\right)=(i, j) \mid\left(X_{1}(0), X_{2}(0)\right)=\left(i_{0}, j_{0}\right)\right\}
$$

ada dan tidak bergantung kepada nilai awal $\left(i_{0}, j_{0}\right)$. Nilai $\pi_{i, j}$ ini dapat diinterpretasikan sebagai proporsi waktu dari sistem berada di keadaan $(i, j)$ setelah sistem berjalan lama. Nilai $\pi_{i, j}$ bisa didapatkan dengan menyelesaikan sistem 


$$
\begin{aligned}
& \pi \mathbf{Q}=\mathbf{0}, \\
& \pi \mathbf{e}=1
\end{aligned}
$$

dengan $\mathbf{Q}$ menyatakan matrik generator yang diperoleh dengan menerapkan teknik balance equation (lihat Ross[10]) dengan bantuan diagram laju transisi seperti yang terlihat di gambar 2, dan e menyatakan vektor kolom dengan semua elemennya bernilai 1 .

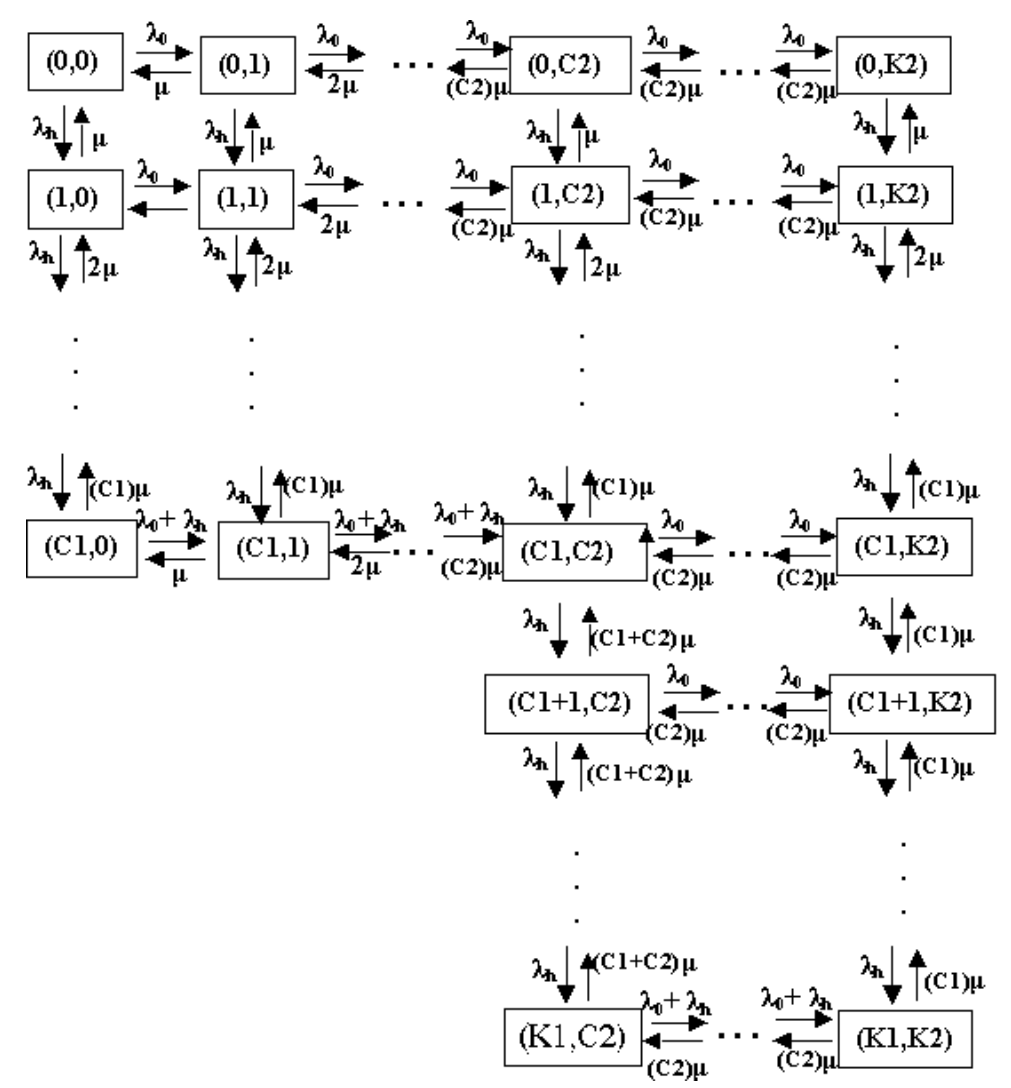

Gambar 4 Diagram laju transisi untuk jaringan antrian yang diteliti.

Di bagian berikutnya kita akan menurunkan ekspresi untuk dropping probability dan blocking probability secara ekplisit dalam nilai-nilai $\pi_{i, j}$.

\section{Rumus untuk Dropping Probability dan Blocking Probability}

Di bagian ini kita akan meneliti peristiwa blocking, yaitu peristiwa tertolaknya sinyal permintaan handoff atau originating call karena sewaktu kedatangan sinyal tersebut sistem antrian dalam keadaan penuh. Setelah itu kita akan 
meneliti peristiwa dropping, yaitu peristiwa terputusnya hubungan komunikasi karena proses handoff gagal dilaksanakan. Nilai-nilai dropping probability dan blocking probability akan kita turunkan secara eksplisit dalam bentuk distribusi stasioner $\pi_{i, j}$.

\subsection{Blocking Probability Permintaan Hubungan Baru}

Dengan sistem reservasi kanal seperti yang telah dijelaskan di bagian 2, permintaan hubungan baru akan ditolak (blocking) apabila pada saat kedatangan sinyal tersebut sistem antrian 2 penuh, dan tidak bergantung kepada keadaan di sistem antrian 1. Misalkan $P_{B O}$ menyatakan nilai blocking probability dari permintaan hubungan baru ini. Maka

$$
P_{B O}=\sum_{i=0}^{K_{1}} \pi_{i, K_{2}}
$$

\subsection{Blocking Probability dan Dropping Probability Permintaan Handoff}

Berbeda dengan sinyal permintaan hubungan baru, sinyal handoff akan diblok jika pada saat kedatangannya sistem antrian 1 dan sistem antrian 2 penuh. Jika kita notasikan blocking probability dari permintaan handoff isi dengan $P_{B H}$, maka

$$
P_{B H}=\pi_{K_{1}, K_{2}}
$$

Selanjutnya kita akan menurunkan ekspresi untuk dropping probability permintaan handoff. Peristiwa dropping akan terjadi apabila:

(i) sinyal handoff mengalami peristiwa blocking, atau

(ii) sinyal handoff yang berada di antrian tidak mendapatkan kanal kosong sampai waktu tempuh dalam handoff area (dinotasikan $w$ ) habis.

Ingat bahwa dengan pemberian prioritas seperti yang telah dijelaskan di bagian 2, suatu sinyal handoff dapat mengantri di sistem antrian 1 atau di sistem antrian 2. Di bawah ini akan kita turunkan distribusi dari waktu tunggu sinyal handoff di sistem antrian 1. Distribusi waktu tunggu di sistem antrian 2 dapat diturunkan dengan cara yang serupa.

Pandang suatu sinyal handoff yang memasuki antrian di sistem 1. Misalkan ada saat permintaan handoff tersebut datang ke sistem antrian (kita set waktu kedatangan ini sebagai $t_{0}$ ), telah ada $n$ panggilan lain dalam sistem 1 , dengan 
$C_{1} \leq n \leq K_{1}-1$. Definisikan $T_{q 1}$ sebagai waktu tunggu permintaan handoff di antrian $Q_{1}$ pada keadaan steady state, dan $N_{t}$ adalah banyaknya pembicaraan yang telah diselesaikan pada selang $\left(t_{0}, t\right]$. Maka dengan asumsi proses kedatangan sinyal yang mengikuti proses Poisson dan waktu pembicaraan yang berdistribusi eksponensial,

$P\left\{T_{q 1}>w \mid n\right.$ sinyal lain di sistem 1 pada saat $\left.t_{0}\right\}=P\left\{N(t) \leq n-C_{1}\right\}$

$$
=\sum_{k=0}^{n-C_{1}} \frac{\left(\mu C_{1} w\right)^{k}}{k !} e^{-\mu C_{1} w},
$$

sehingga

$$
P\left\{T_{q 1}>w\right\}=\sum_{i=C_{1}}^{K_{1}-1} \sum_{j=C_{2}}^{K_{2}} \sum_{k=0}^{i-C_{1}} e^{-\mu C_{1} w} \frac{\left(\mu C_{1} w\right)^{k}}{k !} \pi_{i, j} .
$$

Sekarang pandang kasus ke dua, di mana sinyal handoff harus mengantri di sistem antrian 2. Artinya sinyal handoff tersebut pada saat kedatangannya menemukan sistem antrian 1 penuh, tetapi masih ada tempat kosong di antrian sistem 2. Maka untuk $w \geq 0$,

$$
P\left\{T_{q 2}>w\right\}=\sum_{j=C_{2}}^{K_{2}-1} \sum_{k=0}^{j-C_{2}} e^{-\mu C_{2} w} \frac{\left(\mu C_{2} w\right)^{k}}{k !} \pi_{K_{1}, j}
$$

Dengan menerapkan law of total probability, dari persamaan (5) dan (6) kita dapatkan untuk $w>0$,

$$
\begin{aligned}
& P\{\text { waktu mengantri }>w\} \\
& =\sum_{i=C_{1}}^{K_{1}-1} \sum_{j=C_{2}}^{K_{2}} \sum_{k=0}^{i-C_{1}} e^{-\mu C_{1} w} \frac{\left(\mu C_{1} w\right)^{k}}{k !} \pi_{i, j}+\sum_{j=C_{2}}^{K_{2}-1} \sum_{k=0}^{j-C_{2}} e^{-\mu C_{2} w} \frac{\left(\mu C_{2} w\right)^{k}}{k !} \pi_{K_{1}, j}
\end{aligned}
$$

Sehingga besarnya dropping probability permintaan handoff, yang kita notasikan dengan $P_{D H}$, adalah

$$
\begin{aligned}
P_{D H} & =\pi_{K_{1}, K_{2}}+\sum_{i=C_{1}}^{K_{1}-1} \sum_{j=C_{2}}^{K_{2}} \sum_{k=0}^{i-C_{1}} e^{-\mu C_{1} w} \frac{\left(\mu C_{1} w\right)^{k}}{k !} \pi_{i, j} \\
& +\sum_{j=C_{2}}^{K_{2}-1} \sum_{k=0}^{j-C_{2}} e^{-\mu C_{2} w} \frac{\left(\mu C_{2} w\right)^{k}}{k !} \pi_{K_{1}, j}
\end{aligned}
$$




\section{$4 \quad$ Matrix Analytic Technique Untuk Sistem Persamaan (1)}

Untuk mendapatkan distribusi peluang stasioner $\boldsymbol{\pi}$, kita harus menyelesaikan sistem persamaan (1) yang terdiri dari $\left[\left(C_{1}+1\right) \times\left(C-C_{1}+Q_{2}\right)\right]+\left[Q_{1} \times\left(Q_{2}+1\right)\right]$ +1 persamaan. Jika nilai $C_{1}$ yang cukup besar, maka banyaknya persamaan yang termuat di sistem (1) akan semakin besar. Teknik penyelesaian persamaan linear yang konvensional tidak akan efektif jika kita gunakan untuk menyelesaikan sistem tersebut. Untuk itu, diperlukan satu teknik khusus untuk menyelesaikan sistem (1). Di makalah ini kita akan menerapkan Matrix Analytic Technique pada sistem sistem (1), dengan terlebih dahulu membuat penomoran elemenelemen di ruang keadaan $S$ yang diatur oleh pengaitan

$$
t:(i, j) \mapsto \begin{cases}i\left(K_{2}+1\right)+j+1, & i \leq C_{1}, \\ \left(C_{1}+1\right)\left(K_{2}+1\right)+\left(i-C_{1}-1\right)+j-C_{2}+1, & i>C_{1} .\end{cases}
$$

Pengaitan tersebut mendefinisikan korespondensi satu-satu antara himpunan $S$ dan himpunan $\{1,2, \ldots$,$\} . Dengan pengaitan itu pula kita dapat menuliskan$ matriks $\mathbf{Q}$ menjadi matriks blok berikut ini.

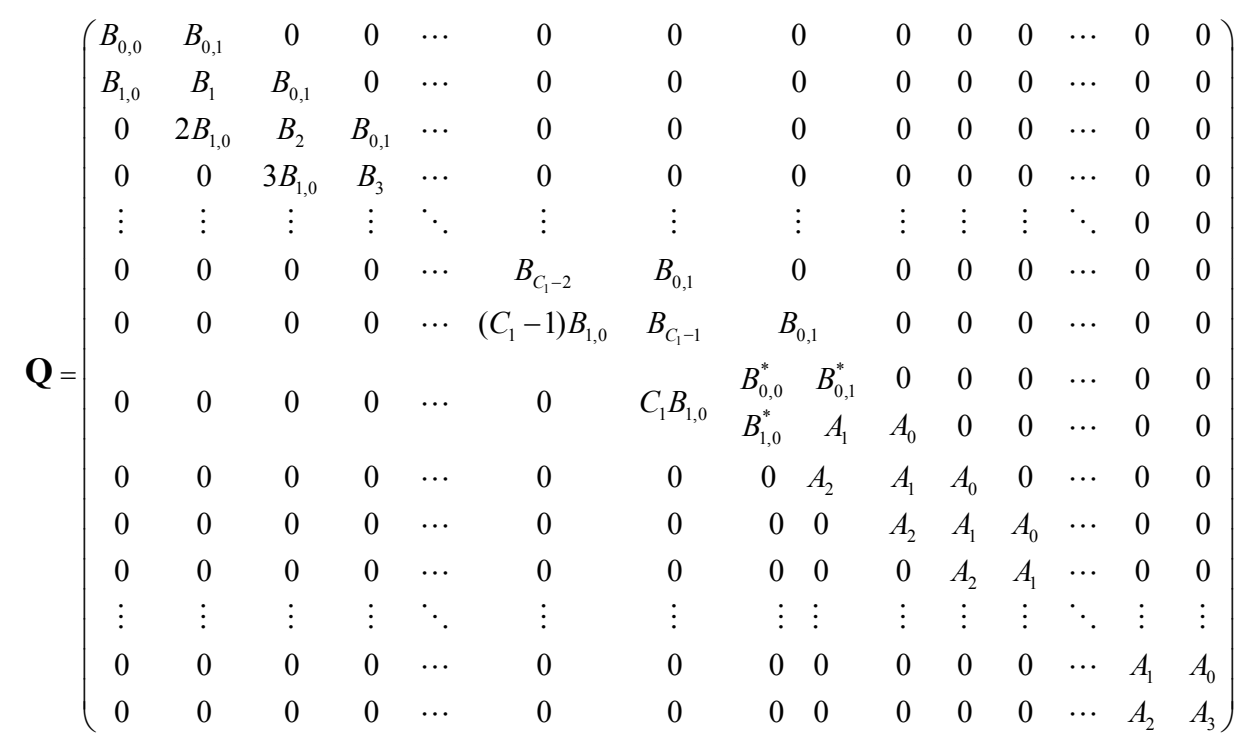

dengan

- $\mathbf{B}_{0,0}$ adalah matriks berukuran $\left(K_{2}+1\right) \times\left(K_{2}+1\right)$ yang didefinisikan sebagai: 


$$
\mathbf{B}_{0,0}=\left(\begin{array}{cccccc}
-\left(\lambda_{0}+\lambda_{h}\right) & \lambda_{0} & 0 & \cdots & 0 & 0 \\
\mu & -\left(\lambda_{0}+\lambda_{h}+\mu\right) & \lambda_{0} & \cdots & 0 & 0 \\
0 & 2 \mu & -\left(\lambda_{0}+\lambda_{h}+2 \mu\right) & \cdots & 0 & 0 \\
\vdots & \vdots & \vdots & \ddots & \vdots & \vdots \\
0 & 0 & 0 & \cdots & -\left(\lambda_{0}+\lambda_{h}+\left(C_{2}-1\right) \mu\right) & \lambda_{0} \\
0 & 0 & 0 & \cdots & C_{2} \mu & -\left(\lambda_{h}+C_{2} \mu\right)
\end{array}\right),
$$

- untuk $j=1,2, \cdots, C_{1}-1$, matriks-matriks $\mathbf{B}_{j}$ berukuran $\left(\mathrm{K}_{2}+1\right) \times\left(\mathrm{K}_{2}+1\right)$ yang didefiniskan sebagai

$$
\mathbf{B}_{j}=\mathbf{B}_{0,0}-j \mu \mathbf{I},
$$

dengan $\mathbf{I}$ adalah matriks identitas dengan ukuran $\left(\mathrm{K}_{2}+1\right) \times\left(\mathrm{K}_{2}+1\right)$,

- $\mathbf{B}_{0,1}$ dan $\mathbf{B}_{1,0}$ adalah matriks-matriks yang berukuran $\left(\mathrm{K}_{2}+1\right) \times\left(\mathrm{K}_{2}+1\right)$, yang didefiniskan sebagai

$$
\mathbf{B}_{0,1}=\operatorname{diag}\left(\lambda_{h}, \cdots, \lambda_{h}\right)
$$

- $\quad \mathbf{B}_{0,0}^{*}$ adalah matriks berukuran $C_{2} \times C_{2}$ yang didefinisikan sebagai

$$
\mathbf{B}_{0,0}^{*}=\left(\begin{array}{ccccc}
-b_{0} & \lambda_{0}+\lambda_{h} & 0 & \cdots & 0 \\
\mu & -b_{1} & \lambda_{0}+\lambda_{h} & \cdots & 0 \\
0 & 2 \mu & -b_{2} & \cdots & 0 \\
\vdots & \vdots & \vdots & \ddots & \vdots \\
0 & 0 & 0 & \cdots & \lambda_{0}+\lambda_{h} \\
0 & 0 & 0 & \cdots & -b_{C_{2}-1}
\end{array}\right)
$$

dengan $b_{i}=\lambda_{0}-\lambda_{h}-i \mu$ untuk $i=0, \cdots, C_{2}-1$,

- $\quad \mathbf{B}_{0,1}^{*}$ adalah matriks berukuran $C_{2} \times\left(Q_{2}+1\right)$ yang didefinisikan sebagai

$$
\mathbf{B}_{0,1}^{*}=\left(\begin{array}{ccccc}
\lambda_{h} & 0 & 0 & \cdots & 0 \\
0 & \lambda_{h} & 0 & \cdots & 0 \\
\vdots & \vdots & \vdots & \ddots & \vdots \\
0 & 0 & 0 & \cdots & \lambda_{h} \\
0 & 0 & 0 & \cdots & 0 \\
\vdots & \vdots & \vdots & \ddots & \vdots \\
0 & 0 & 0 & \cdots & 0
\end{array}\right)
$$


- $\quad \mathbf{B}_{1,0}^{*}$ adalah matriks berukuran $\left(Q_{2}+1\right) \times C_{2}$ yang didefinisikan sebagai

$$
\mathbf{B}_{1,0}^{*}=\left(\begin{array}{cccccccc}
\mu & 0 & 0 & \cdots & 0 & 0 & \cdots & 0 \\
0 & \mu & & \cdots & 0 & 0 & \cdots & 0 \\
\vdots & \vdots & \vdots & \ddots & \vdots & \vdots & \vdots & \vdots \\
0 & 0 & 0 & \cdots & \mu & 0 & \cdots & 0
\end{array}\right)
$$

- untuk $i=0,1, \cdots, 3, \mathbf{A}_{\mathbf{i}}$ adalah matriks berukuran $\left(Q_{2}+1\right) \times\left(Q_{2}+1\right)$ yang didefinisikan oleh:

$$
\begin{aligned}
& A_{0}=\operatorname{diag}\left(\lambda_{h}, \cdots, \lambda_{h}\right) \\
& A_{1}=\left(\begin{array}{ccccccc}
b & \lambda_{0} & 0 & \cdots & \cdots & 0 & 0 \\
c_{2} \mu & b & \lambda_{0} & 0 & \cdots & 0 & 0 \\
0 & c_{2} \mu & b & \lambda_{0} & 0 & \cdots & 0 \\
\vdots & \vdots & \vdots & \vdots & \ddots & \vdots & \vdots \\
0 & 0 & 0 & 0 & c_{2} \mu & b & \lambda_{0} \\
0 & 0 & 0 & 0 & \cdots & c_{2} \mu & -\left(\lambda_{h}+C \mu\right)
\end{array}\right) \\
& A_{2}=\left(\begin{array}{ccccccc}
C \mu & 0 & 0 & \cdots & \cdots & 0 & 0 \\
0 & C_{1} \mu & 0 & 0 & \cdots & 0 & 0 \\
0 & 0 & C_{1} \mu & 0 & 0 & \cdots & 0 \\
\vdots & \vdots & \vdots & \vdots & \ddots & \vdots & \vdots \\
0 & 0 & 0 & 0 & 0 & C_{1} \mu & 0 \\
0 & 0 & 0 & 0 & \cdots & 0 & C_{1} \mu
\end{array}\right) \\
& A_{3}=\left(\begin{array}{ccccccc}
b & \lambda_{0}+\lambda_{h} & 0 & \cdots & \cdots & 0 & 0 \\
c_{2} \mu & b & \lambda_{0}+\lambda_{h} & 0 & \cdots & 0 & 0 \\
0 & c_{2} \mu & C_{1} \mu & \lambda_{0}+\lambda_{h} & 0 & \cdots & 0 \\
\vdots & \vdots & \vdots & \vdots & \ddots & \vdots & \vdots \\
0 & 0 & 0 & 0 & c_{2} \mu & b & \lambda_{0}+\lambda_{h} \\
0 & 0 & 0 & 0 & \cdots & c_{2} \mu 0 & -C \mu
\end{array}\right)
\end{aligned}
$$

dengan $b=-\left(\lambda_{0}+\lambda_{h}+C \mu\right)$. 
Matriks Q di sistem (1) setelah kita tuliskan menjadi suatu matriks blok, tidak mempunyai keteraturan seperti yang dipunyai oleh matriks generator Quasi Birth-Death Process (lihat halaman 130 di [1] atau [7]), di mana Matrix Analytic Technique banyak diterapkan. Tetapi kita akan melihat keteraturan seperti itu pada sub-sub matriks $\mathbf{S}_{1}$ dan $\mathbf{S}_{2}$ dari $\mathbf{Q}$ seperti yang kita definisikan di bawah ini. Kita menerapkan Matrix Analytic Technique pada kedua sub matriks ini secara paralel, kemudian menggabungkan hasilnya untuk mendapatkan solusi dari sistem (1).

Misalkan $\mathbf{S}_{1}$ adalah sub matriks $\mathbf{Q}$ yang berukuran $\left[\left(C_{1}+1\right)\left(C_{2}+1\right)\right] \times$ $\left[C_{1}\left(C_{2}+1\right)\right]$, dan $\mathbf{S}_{2}$ adalah sub matriks $\mathbf{Q}$ yang berukuran $\left[\left(2 C_{2}+1\right)\left(K_{1}-C_{1}\right)\right] \times$ $\left[C_{2}+\left(K_{1}-C_{1}\right)\right]$ yang kita definisikan seperti di gambar 5 .

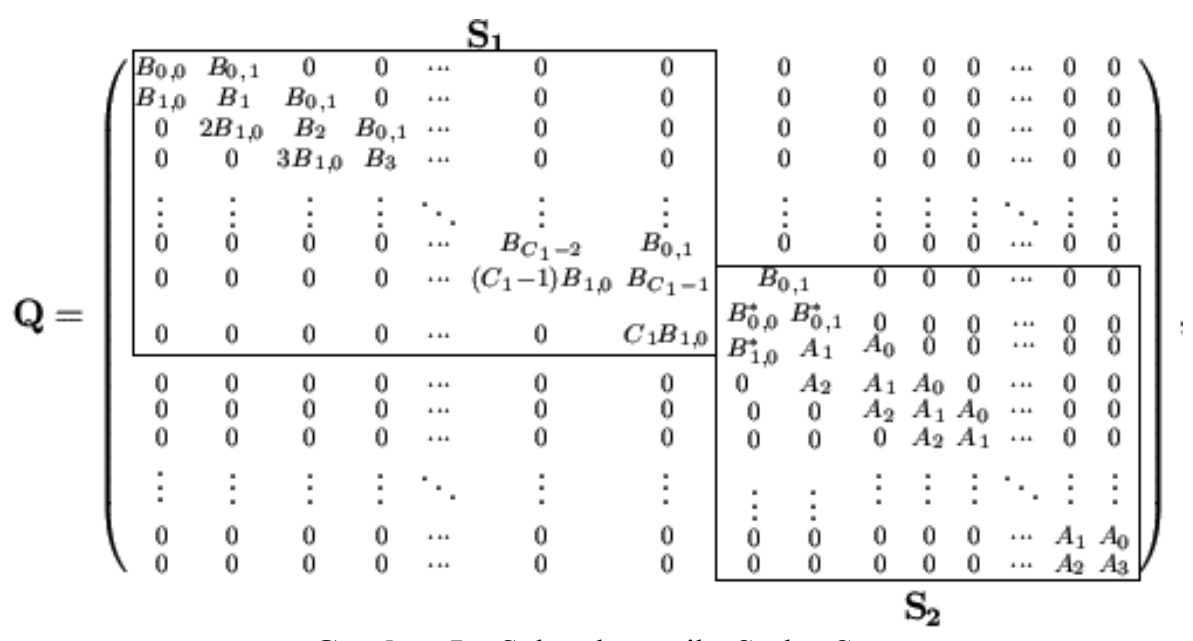

Gambar 5 Sub-sub matriks $\mathbf{S}_{1}$ dan $\mathbf{S}_{2}$.

Misalkan

$$
\tilde{\boldsymbol{\pi}}_{i}=\left(\pi_{i, 0}, \pi_{i, 1}, \pi_{i, 2}, \cdots, \pi_{i,\left(K_{2}\right)}\right)
$$

dan

$$
\mathbf{p}_{C_{1}+i}=\left(\pi_{C_{1}+i, C_{2}}, \pi_{C_{1}+i, C_{2}+1} \cdots, \pi_{C_{1}+i, K_{2}}\right)
$$

Distribusi peluang stasioner $\pi$ sekarang dapat dituliskan menjadi

$$
\boldsymbol{\pi}=\left(\tilde{\boldsymbol{\pi}}_{0}, \tilde{\boldsymbol{\pi}}_{1}, \cdots, \tilde{\boldsymbol{\pi}}_{C_{1}-1}, \tilde{\boldsymbol{\pi}}_{C_{1}}, \mathbf{p}_{C_{1}+2}, \mathbf{p}_{2}, \mathbf{p}_{3}, \cdots, \mathbf{p}_{K_{1}}\right)
$$

dengan

$$
\tilde{\pi}_{C_{1}}=\left(\pi_{C_{1}, 0}, \cdots, \pi_{C_{1},\left(C_{2}-1\right)}, \mathbf{p}_{C_{1}+1}\right)
$$


Di dua sub-bagian setelah ini kita akan menerapkan teknik analitik matriks pada sub-sub matriks $\mathbf{S}_{1}$ dan $\mathbf{S}_{2}$ masing-masing untuk mendapatkan vektorvektor $\tilde{\pi}_{i}$ untuk $i=0,1, \cdots, C_{1}$ dan $\mathbf{p}_{j}$ untuk $j=C_{1}+1, C_{1}+2, \cdots, K_{1}$.

\subsection{Metoda Analitik Matriks untuk $S_{1}$}

Sub matriks $\mathbf{S}_{1}$ mempunyai pola geometri yang sama dengan matriks generator Quasi Birth-Death Process (lihat halaman 130 di [1]). Dari sistem persamaan (1), dengan menggunakan notasi di (9), kita dapatkan hubungan

$$
\begin{gathered}
\tilde{\boldsymbol{\pi}}_{0} \mathbf{B}_{0,0}+\tilde{\boldsymbol{\pi}}_{1} \mathbf{B}_{1,0}=\mathbf{0} \\
\tilde{\boldsymbol{\pi}}_{i-1} \mathbf{B}_{0,1}+\tilde{\boldsymbol{\pi}}_{i}\left(\mathbf{B}_{0,0}-i \mu \mathbf{I}\right)+(i+1) \mathbf{B}_{1,0} \tilde{\boldsymbol{\pi}}_{i+1}=\mathbf{0}, \quad 1 \leq i \leq C_{1}-1 .
\end{gathered}
$$

Dari hubungan-hubungan tersebut kita dapatkan

$$
\tilde{\boldsymbol{\pi}}_{i}=\tilde{\boldsymbol{\pi}}_{i+1}(i+1) \mathbf{B}_{1,0} \mathbf{D}_{i}^{-1}
$$

dengan

$$
\mathbf{D}_{i}=i \mu \mathbf{I}-\mathbf{B}_{0,0}-i \mathbf{B}_{1,0} \mathbf{D}_{i-1}^{-1} \mathbf{B}_{0,1}, \quad 0 \leq i \leq C_{1}-1 .
$$

Dari persamaan (13) kita ketahui bahwa vektor-vektor $\tilde{\boldsymbol{\pi}}_{i}$ untuk $i=0,1, \cdots, C_{1}-1$ dapat kita peroleh langsung jika kita ketahui vektor $\tilde{\boldsymbol{\pi}}_{C_{1}}$ dan matriks-matriks $\mathbf{D}_{i}, i=0,1, \cdots, C_{1}-1$ yang didapat dari hubungan (14). Teknik untuk menentukan vektor $\tilde{\boldsymbol{\pi}}_{C_{1}}$ ini bisa kita dapatkan setelah mengetahui penyelesaian untuk sub sistem yang menyangkut sub matriks $\mathbf{S}_{2}$, seperti yang dijelaskan di sub bagian berikut ini.

\subsection{Metoda Analitik Matriks untuk $\mathrm{S}_{2}$}

Sub matriks $\mathbf{S}_{\mathbf{2}}$ mempunyai pola geometri yang sama dengan matriks generator dari sistem antrian $M /$ Hypo2/1 (A. Riska [1]). Dari sistem persamaan (1), dengan menggunakan notasi di (9), kita dapatkan hubungan-hubungan:

$$
\begin{aligned}
\mathbf{p}_{j-1} \mathbf{A}_{0}+\mathbf{p}_{j} \mathbf{A}_{1}+\mathbf{p}_{j+1} \mathbf{A}_{2} & =\mathbf{0}, \quad j=C_{1}+2, \cdots, K_{1}-1, \\
\mathbf{p}_{K_{1}-1} \mathbf{A}_{0}+\mathbf{p}_{K_{1}} \mathbf{A}_{3} & =\mathbf{0} .
\end{aligned}
$$

Hubungan-hubungan tersebut membawa kita pada dugaan, berdasarkan bentuk penyelesaian di sistem $M / M / 1$ bahwa vektor-vektor $\mathbf{p}_{j}$ untuk $j=C_{1}+2, \cdots, K_{1}$ mempunyai bentuk geometri 


$$
\mathbf{p}_{C_{1}+j}=\mathbf{p}_{1} \mathbf{R}^{j-1}, \quad j=2, \cdots, Q_{1}
$$

dengan $\mathbf{R}$ adalah suatu matriks konstan. Dari dugaan ini, kita akan mendapatkan hubungan

$$
\mathbf{A}_{0}+\mathbf{R} \mathbf{A}_{1}+\mathbf{R}^{2} \mathbf{A}_{2}=\mathbf{0},
$$

yang merupakan persamaan kunci untuk mendapatkan matriks konstan $\mathbf{R}$. Matriks $\mathbf{R}$ dapat diperoleh dengan menyelesaikan persamaan (17) secara numerik (lihat [6] atau [7]).

\subsection{Metoda Agregat untuk Mendapatkan Penyelesaian Sistem (1)}

Dari persamaan (13) dan (10) kita mengetahui bahwa vektor-vektor $\tilde{\boldsymbol{\pi}}_{i}$ untuk $i=0,1, \cdots, C_{1}-1$ dan $\mathbf{p}_{j}$ untuk $j=C_{1}+1, C_{1}+2, \cdots, K_{1}$ dapat kita tuliskan sebagai sebagai fungsi dari vektor $\tilde{\pi}_{C_{1}}=\left(\pi_{C_{1}, 0}, \cdots, \pi_{C_{1},\left(C_{2}-1\right)}, p_{C_{1}+1}\right)$. Vektor $\tilde{\boldsymbol{\pi}}_{C_{1}}$ sendiri, dari sistem (1) dan persamaan (10), memenuhi hubungan

$$
\tilde{\boldsymbol{\pi}}_{C_{1}-1} \mathbf{B}_{0,1}+\tilde{\boldsymbol{\pi}}_{C_{1}} \mathbf{M}=\mathbf{0}
$$

dengan

$$
\mathbf{M}=\left(\begin{array}{cc}
\mathbf{B}_{0,0}^{*} & \mathbf{B}_{0,1}^{*} \\
\mathbf{B}_{1,0}^{*} & \mathbf{A}_{1}+\mathbf{R} \mathbf{A}_{2}
\end{array}\right)
$$

Dengan mensubstitusikan persamaan (13) untuk $i=C_{1}-1$ ke (18), kita peroleh sistem persamaan

$$
\tilde{\boldsymbol{\pi}}_{C_{1}}=\tilde{\boldsymbol{\pi}}_{C_{1}} C_{1} \mathbf{B}_{1,0} \mathbf{D}_{C_{1}-1}^{-1} \mathbf{B}_{0,1}(-\mathbf{M})^{-1} .
$$

Sistem persamaan ini mempunyai penyelesaian yang tidak tunggal. Karena itu, untuk mendapatkan vektor distribusi stasioner $\boldsymbol{\pi}$ kita pertimbangkan juga persamaan normalisasi

$$
\boldsymbol{\pi} \mathbf{1}=1,
$$

yang dalam ekspresi (13) dan (10) dapat dituliskan menjadi persamaan

$$
\begin{aligned}
1 & =\sum_{i=0}^{C_{1}-1} \tilde{\boldsymbol{\pi}}_{i} \mathbf{1}_{\left(\mathrm{C}_{2}+\mathbf{1}\right)}+\tilde{\boldsymbol{\pi}}_{\mathrm{C}_{1}} \mathbf{1}_{\left(\mathrm{C}_{2}+\mathbf{1}\right)}+\mathbf{p}_{\mathrm{C}_{1}+\mathbf{1}} \sum_{\mathbf{j}=\mathbf{2}}^{\mathbf{Q}_{1}} \mathbf{R}^{\mathbf{j}-1} \mathbf{1}_{\mathbf{Q}_{\mathbf{1}}+\mathbf{1}} \\
& =\tilde{\boldsymbol{\pi}}_{C_{1}} \sum_{i=1}^{C_{1}} \prod_{k=0}^{i-1}\left(C_{1}-k\right) \prod_{l=1}^{i} \mathbf{B}_{1,0} \mathbf{D}_{C_{1}-l}^{-1} \mathbf{1}_{\left(\mathrm{C}_{2}+1\right)}+\mathbf{p}_{\mathrm{C}_{1}+1} \sum_{\mathbf{j}=\mathbf{2}}^{\mathbf{Q}_{1}} \mathbf{R}^{\mathbf{j}-\mathbf{1}} \mathbf{1}_{\mathbf{Q}_{1}+\mathbf{1}} .
\end{aligned}
$$




\subsection{Contoh Numerik}

Di bagian ini kita akan melihat contoh bagaimana teknik Analitik Matriks dapat kita terapkan untuk menyelesaikan sistem (1). Contoh sederhana yang diberikan di bagian ini adalah contoh di mana kita tidak memberikan antrian di sistem antrian 2. Akibatnya matriks-matriks $\mathbf{A}_{i}, i=0, \cdots, 3$ berukuran $1 \times 1$ sehingga persamaan (17) dapat diselesaikan secara analitik. Dengan pemilihan kasus seperti ini, metode Analitik Matriks untuk sub matriks $\mathbf{S}_{2}$ dapat dipahami secara gampang. Untuk kasus yang lebih umum, yaitu kasus di mana kita memberikan antrian di sistem antrian 2, penyelesaian persamaan (17) dapat mengacu ke metode yang ditawarkan di [6] atau [7].

Kita pandang sistem telekomunikasi bergerak seluler dengan parameterparameter:

(i) $\mu=0.5$ percakapan $/$ menit.

(ii) $\lambda_{0}=0.5$ panggilan $/$ menit.

(iii) $\lambda_{h}=1$ panggilan/menit.

(iv) Waktu pendudukan dalam handoff area $\left(w_{t}=\right) 1$ menit.

Misalkan terdapat 4 kanal yang dapat dipergunakan untuk hubungan telekomunikasi. Dua diantaranya kita reserve hanya untuk pelayanan sinyal handoff, dengan memberikan satu tempat mengantri di antrian untuk sinyal handoff. Jadi sistem antrian yang kita dapati di contoh ini adalah sistem antrian $M_{1} \overrightarrow{+} M_{2} / M / 2+2(1,0)$.

Sub-sub matriks dari matriks generator $\mathbf{Q}$ untuk contoh kasus ini adalah:

- $\mathbf{B}_{0,0}=\left(\begin{array}{ccc}-1.5 & 0.5 & 0 \\ 0.5 & -2 & 0.5 \\ 0 & 1 & -2\end{array}\right), \mathbf{B}_{0,1}=\left(\begin{array}{ccc}1 & 0 & 0 \\ 0 & 1 & 0 \\ 0 & 0 & 1\end{array}\right), \mathbf{B}_{1,0}=\left(\begin{array}{ccc}0.5 & 0 & 0 \\ 0 & 0.5 & 0 \\ 0 & 0 & 0.5\end{array}\right)$,

- $\mathbf{B}_{0,0}^{*}=\left(\begin{array}{cc}-1.5 & 1.5 \\ 0.5 & -2\end{array}\right), \mathbf{B}_{0,1}^{*}=\left(\begin{array}{l}1 \\ 0\end{array}\right), \mathbf{B}_{1,0}^{*}=\left(\begin{array}{ll}0.5 & 0\end{array}\right)$

$\mathbf{A}_{0}=\left(\lambda_{h}\right)=(1)$

$\mathbf{A}_{1}=\left(-\left(\lambda_{h}+C_{1} \mu+C_{2} \mu\right)\right)=(-3)$

$\mathbf{A}_{2}=\left(C_{1} \mu+C_{2} \mu\right)=(2)$

$\mathbf{A}_{3}=\left(-\left(C_{1} \mu+C_{2} \mu\right)\right)=(-2)$. 
Matriks konstan R, menurut (17) memenuhi persamaan

$$
1-3 \mathbf{R}+2 \mathbf{R}^{2}=0
$$

yang memberikan nilai $\mathbf{R}_{1}=1$ dan $\mathbf{R}_{2}=0.5$. Karena vektor $\mathbf{p}_{j}$ untuk $j=C_{1}+2, \cdots, K_{1}$ merupakan sub-sub vektor distribusi peluang stasioner, maka kita pilih $\mathbf{R}=0.5$.

Matriks-matriks $\mathbf{D}_{i}^{-1}$ yang terlibat di contoh kasus ini adalah:

$$
\mathbf{D}_{0}^{-1}=\left(\begin{array}{lll}
0.7368 & 0.2105 & 0.0526 \\
0.2105 & 0.6316 & 0.1579 \\
0.1053 & 0.3158 & 0.5789
\end{array}\right), \quad \mathbf{D}_{1}^{-1}=\left(\begin{array}{lll}
1.2043 & 0.5806 & 0.2151 \\
0.5806 & 1.0538 & 0.3656 \\
0.4301 & 0.7312 & 0.8387
\end{array}\right)
$$

dan

$$
\mathbf{M}=\left(\begin{array}{cc}
B_{0,0}^{*} & B_{0,1}^{*} \\
B_{1,0}^{*} & A_{1}+\mathbf{R} A_{2}
\end{array}\right)=\left(\begin{array}{ccc}
-2.5 & 1.5 & 0 \\
0.5 & -3 & 1.5 \\
0 & 1 & -2
\end{array}\right)
$$

Berdasarkan (19), diperoleh

$$
\begin{aligned}
& \tilde{\boldsymbol{\pi}}_{2}=\tilde{\boldsymbol{\pi}}_{2}\left(\begin{array}{lll}
0.6264 & 0.7235 & 0.6501 \\
0.3948 & 0.8128 & 0.7924 \\
0.3165 & 0.7224 & 0.9611
\end{array}\right) \text {, yang memberikan penyelesaian } \\
& \tilde{\boldsymbol{\pi}}_{2}=(0.4263 t, 0.8616 t, t)
\end{aligned}
$$

untuk suatu bilangan real $t$. Selanjutnya kita akan menggunakan persamaan normalisasi (20) untuk mencari nilai $t$ yang akan membuat $\boldsymbol{\pi}$ suatu vektor distribusi peluang stasioner, atau $\boldsymbol{\pi} \mathbf{1}=1$.

Definisikan untuk $i=0,1,2, \tilde{\pi}_{i}^{\prime}=\frac{\tilde{\pi}_{i}}{\pi_{2,2}}$. Maka $\tilde{\pi}_{2}^{\prime}=(0.4263,0.8616,1)$ dan dengan persamaan rekursif $(13), \tilde{\pi}_{1}^{\prime}=(0.6348,0.9455,0.7076)$, dan $\tilde{\pi}_{0}^{\prime}=(0.3707$, $0.4771,0.2962)$. Persamaan normalisasi (20) sekarang dapat dituliskan menjadi

$$
\pi_{2,2}\left(\tilde{\boldsymbol{\pi}}_{0} \mathbf{1}_{3}+\tilde{\boldsymbol{\pi}}_{1} \mathbf{1}_{3}+\tilde{\boldsymbol{\pi}}_{2} \mathbf{1}_{3}+\mathbf{R}\right)=1,
$$

sehingga kita dapatkan 


$$
\begin{aligned}
& \tilde{\boldsymbol{\pi}}_{2}=(0.0685,0.1385,0.1608), \\
& \tilde{\boldsymbol{\pi}}_{1}=(0.1020,0.1520,0.1138), \\
& \tilde{\boldsymbol{\pi}}_{0}=(0.0596,0.0767,0.0476),
\end{aligned}
$$

dan vektor distribusi peluang stasioner kita adalah

$$
\boldsymbol{\pi}=\left(\tilde{\boldsymbol{\pi}}_{0}, \tilde{\boldsymbol{\pi}}_{1}, \tilde{\boldsymbol{\pi}}_{2}, 0.0804\right) .
$$

Dengan distribusi peluang stasioner ini, kita dapat menentukan kinerja sistem yang terkait dengan proses handoff seperti yang dituliskan berikut ini.

Besarnya Blocking Probability permintaan hubungan baru adalah

$$
P_{B O}=\sum_{i=0}^{3} \pi_{i, K_{2}}=0.0476+0.1138+0.1608+0.0804=0.4026,
$$

besarnya Blocking Probability permintaan handoff adalah

$$
P_{B H}=\pi_{K_{1}, K_{2}}=0.0804 \text {. }
$$

Ini menunjukkan bahwa dengan teknik reservasi kanal, nilai Blocking Probability permintaan handoff jauh lebih kecil dibandingkan Blocking Probability untuk permintaan hubungan baru.

Besarnya peluang sinyal handoff harus mengantri terlebih dahulu sebelum dilayani adalah $\pi_{2,2}=0.1608$. Misalkan $T_{q}$ menyatakan peubah acak dari waktu tunggu di antrian 1, dan misalkan rata-rata waktu menjelajahi daerah handoff adalah $w_{t}=1$ menit. Maka sinyal handoff akan terputus secara paksa jika $T_{q}>w_{t}$. Dengan menerapkan hasil analisis untuk sistem antrian $M / M / 2 / 2+1$, untuk contoh kasus yang kita bahas kita peroleh $P\left\{T_{q}>w_{t}\right\}=0.0591$, sehingga besarnya dropping probability permintaan handoff adalah

$$
\begin{aligned}
& P_{D H} \\
= & P\{\text { terputus karena blocking }\} P_{B H}+P\{\text { sinyal harus mengantri }\} P\left\{T_{q}>w_{t}\right\} \\
= & 1 P_{B H}+0.1608 P\left\{T_{q}>w_{t}\right\}=0.0899,
\end{aligned}
$$

yang memenuhi standar Grade of Service, yaitu $\leq 5 \%$. 


\section{$5 \quad$ Diskusi}

Di makalah ini kita telah membahas penerapan Matrix Analytic Technique yang digunakan untuk menganalisis jaringan antrian yang menjadi model pemberian prioritas pada sinyal permintaan handoff. Dengan teknik ini, penentuan jumlah kanal yang harus direservasi agar blocking probability dan dropping probability dari sinyal permintaan handoff minimal dan blocking probability untuk sinyal permintaan hubungan baru yang masih memenuhi standar GoS dapat dilakukan secara cepat.

Teknik ini dapat diterapkan pada sistem yang sama tetapi dengan dua kelas kecepatan gerak pengguna seperti yang diteliti di [8].

\section{Daftar Pustaka}

1. Akimaru, H. \& Kawashima, K., Teletraffic Theory and Applications, Springer-Verlag (1993).

2. Hadianti, R., Naiborhu, J. \& Dahliantini, L., Optimisasi Reservasi Kanal untuk Prosedur Handoff pada Sistem Komunikasi Bergerak Seluler, akan terbit di Prosiding Konferensi Nasional Matematika XII (Juli 2004).

3. Heristyo, A., Penentuan Batas Reservasi yang Optimal untuk Prosedur Handoff di Sistem Telekomunikasi Bergerak Seluler, Tugas Akhir Sarjana, Departemen Matematika ITB (2004).

4. Ioannou, K., et al., Optimizing the Handover Call Blocking Probability in Cellular Networks with High Speed Moving, IEEE Communications Letters, 6(10), p. 422-442 (2002).

5. Lee, W. C., Mobile Cellular Telecommunications Systems, McGraw-Hill (1989).

6. Nelson, R., Probability, Stochastic Processes, and Queueing Theory: The Mathematics of Computer Performance Modeling, Springer-Verlag (1995).

7. Neuts, M. F., Matrix Geometric Solutions in Stochastic Models, John Hopkins University Press (1981).

8. Radityo, S., Analisa Unjuk Kerja Sistem Komunikasi Bergerak Seluler dengan Prosedur Prioritas Handoff Dua Tingkat, Tugas Akhir Sarjana, Departemen Teknik Elektro, STT Telkom Bandung (2001).

9. Riska, A., Aggregate Matrix Analytic Techniques and their Applicability in Computer Systems Performance Analysis, Ph.D thesis, Department of Computer Sciences, The College of William \& Mary (2001).

10. Ross, S. M., Stochastic Processes, second edition, John Wiley \& Sons, New York (1995). 